doi: 10.2478/v10221-011-0010-7

\title{
Economic aspects of obesity prevention
}

\section{Ekonomski vidiki preprečevanja debelosti}

\author{
Michele Cecchini ${ }^{1}$, Franco Sassi ${ }^{1}$
}

${ }^{1}$ Health Division, OECD, 2 rue André Pascal, 75016 Paris, France

e-mail: franco.sassi@oecd.org

pregledni znanstveni članek

UDK:613.2:339.13

članek prispel: 1. 6. 2011; članek sprejet: 14. 7. 2011

citirajte članek kot / cite this article as:

Bilt - Ekon Organ Inform Zdrav 2011; 27(2): 77-94

\begin{abstract}
Governments in OECD countries have intervened in a variety of ways to improve diets, increase physical activity and tackle obesity in recent years. The preventive interventions assessed in this analysis are drawn from the most commonly used approaches, including: health education and health promotion (mass media campaigns, school-based interventions, worksite interventions); regulation and fiscal measures (fiscal measures altering the prices of healthy and unhealthy foods, regulation of food advertising to children and mandatory nutrition labelling); and, counselling of individuals at risk in primary care. This report examines the characteristics, the costs and the relative success of each approach in improving health outcomes and social disparities in health, with specific reference to the European context.
\end{abstract}

Key words: cost-effectiveness, obesity, prevention

\section{Izvleček}

V zadnjih letih so vlade držav OECD (Organizacije za gospodarsko sodelovanje in razvoj) posredovale na različne načine, da bi izboljšale prehranjevanje, spodbudile povečanje telesne dejavnosti v boju proti debelosti. Preventivni ukrepi, ocenjeni v tej analizi, so sestavljeni iz naslednjih najpogosteje uporabljenih pristopov: 
zdravstvena vzgoja in promocija zdravja (akcije javnega obveščanja, v šolah in na delovnem mestu), pravna ureditev in fiskalni ukrepi (fiskalni ukrepi spreminjajo cene zdrave in nezdrave hrane, urejajo oglaševanje hrane za otroke in predpisujejo obvezno označevanje hranilne vrednosti) ter svetovanje posameznikom, ki sodijo v bolj izpostavljene skupine, na ravni primarnega zdravstva. Prispevek preučuje lastnosti, stroške in relativni uspeh vsakega pristopa pri izboljšanju zdravstvenih rezultatov in socialnih razlik v zdravju s posebnim poudarkom na evropsko okolje.

Ključne besede: stroškovne učinkovitosti, debelost, preprečevanje

\section{What interventions can improve diets and increase physical activity?}

Governments in OECD countries have considered or implemented numerous interventions to improve diets, increase physical activity and tackle obesity in recent years. Building on reviews ${ }^{1}$ by $W H O$ and OECD, it has been possible to identify a relatively small but important evidence base on the impact of nine different health interventions on individual health-related behaviours, obesity and other risk factors for chronic diseases. The nine interventions, listed below within three main groups, formed the object of an economic analysis undertaken by the OECD to assess the cost-effectiveness and the distributional impact of different means of preventing chronic diseases, based on a mathematical model jointly developed with the WHO (1).

\begin{tabular}{l|l|l}
\hline $\begin{array}{l}\text { Health education and } \\
\text { health promotion } \\
\text { interventions }\end{array}$ & $\begin{array}{l}\text { Regulation and fiscal } \\
\text { measures }\end{array}$ & $\begin{array}{l}\text { Primary-care based } \\
\text { interventions }\end{array}$ \\
\hline $\begin{array}{l}\text { Mass media } \\
\text { campaigns }\end{array}$ & $\begin{array}{l}\text { Fiscal measures altering the } \\
\text { prices of fruit and vegetables } \\
\text { and foods high in fat }\end{array}$ & $\begin{array}{l}\text { Physician counselling } \\
\text { of individuals at risk }\end{array}$ \\
\hline $\begin{array}{l}\text { School-based } \\
\text { interventions }\end{array}$ & $\begin{array}{l}\text { Government regulation or } \\
\text { industry self-regulation of } \\
\text { food advertising to children }\end{array}$ & $\begin{array}{l}\text { Intensive physician } \\
\text { and dietician } \\
\text { counselling of } \\
\text { individuals at risk }\end{array}$ \\
\hline $\begin{array}{l}\text { Worksite } \\
\text { interventions }\end{array}$ & Compulsory food labelling & \\
\hline \hline
\end{tabular}

${ }^{1}$ A WHO review of the effectiveness of interventions to improve diets and increase physical activity found that school-based interventions are those most often assessed, while fewer studies focused on other public health interventions (WHO, 2009). The OECD collated the existing evidence concerning the impacts of interventions on diet and physical activity, of which the above WHO review includes a large part. The OECD retrieved a number of studies which were not covered in the WHO review because published after June 2006, not indexed in the literature databases used in the review, or because the relevant interventions were out of the scope of the review. 
The quality and quantity of the evidence available for different interventions vary widely, but mathematical models like the OECD/WHO one can be used to combine multiple sources of evidence to make up for the limitations of individual sources. The OECD/WHO analysis relies on the existing effectiveness evidence to identify possible key characteristics of the nine interventions. Therefore, the interventions considered here, as described in the following sections, reflect the characteristics of those assessed in existing experimental and observational studies, and not necessarily those of interventions which Canada may have adopted or which Canada may be considering to adopt. Interventions may be designed and implemented in a variety of ways, and the evidence presented in this chapter should serve as a guide to policy makers as to what impact may be expected.

The preventive interventions assessed in the analysis reflect a wide variety of approaches and are based in diverse settings. The costs associated with those interventions may arise in different jurisdictions. Some of the costs are typically paid through public expenditure (e.g. the costs associated with regulatory measures), others typically not (e.g. most of the costs associated with worksite interventions). Some of the costs arise within the health sector, others arise within other sectors of government intervention (e.g. most of the costs associated with school-based interventions). Only public sector costs are accounted for in the analysis, while costs borne by the private sector are excluded. All costs are reported in US Dollar Purchasing Power Parities (USD PPPs), with 2005 the chosen base year.

\subsection{Health education and health promotion interventions}

\section{Exploiting the power of the media}

The mass media can reach vast audiences rapidly and directly. Health promotion campaigns broadcast by radio and television may raise awareness of health issues and increase health information and knowledge in a large part of the population. We modeled intervention characteristics and effectiveness on the basis of a selection of studies selected from a broader literature (2-4). The intervention will increase consumption of fruit and vegetables by an average of slightly more than 18 grams per day, and it will increase the proportion of the population undertaking adequate levels of physical activity by approximately $2.4 \%$. The estimated cost of per capita of a mass media campaign in Europe is about 1.8 US\$ PPP.

\section{Targeting children}

School enrolment is nearly universal in the OECD area at younger ages; therefore, schools provide the means for reaching a large audience of children from all backgrounds. Additionally, food preferences are formed during childhood and helping children to develop a taste for healthier foods may have an effect on their diets persisting into their adult life.

The intervention targets all children attending school in the age group 8-9, but it is assumed that just above $60 \%$ of children will fully participate in the activities which 
form part of the intervention. Intervention characteristics and effectiveness are modelled on the basis of a selection of studies selected from a broader literature (5-8). The intervention will modify distal risk factors, particularly by increasing the intake of fruit and vegetables by almost 38 grams per day during the course of the intervention and by decreasing the proportion of energy intake from fats of nearly $2 \%$. The BMI of children exposed to the intervention will be reduced by 0.2 points. The estimated cost per capita of a school-based intervention in Europe is about 2.6 US\$ PPP.

\section{Healthy workplaces}

Working adults spend a large part of their time at the workplace, where they are exposed to a number of factors that may influence their lifestyles and health habits. Existing evidence suggests that health education, peer pressure, and changes in the work environment contribute to changing lifestyles and preventing certain chronic diseases.

The intervention targets individuals between the ages of 18 and 65 working for companies with at least 50 employees. It is assumed that $50 \%$ of employers, and $45 \%$ of their employees, will participate in the programme. Intervention characteristics and effectiveness are based on evidence provided in (9-13). The intervention will increase the consumption of fruit and vegetables by an average of almost 46 grams per day and the proportion of physically active employees by $12 \%$. It will also decrease the proportion of total energy intake from fats by over $2 \%$. Employees exposed to the intervention will have their BMI reduced by, on average, half a point. The estimated cost of per capita of a national worksite intervention in Europe is about 4.51 US\$ PPP.

\subsection{Regulation and fiscal measures}

Using fiscal levers to change people's diets

Fiscal incentives can directly affect consumption behaviours, and therefore influence lifestyle choices. Taxes, tax exemptions and subsidies are widely used in agriculture and food markets in the OECD area. Differential taxation of food products is relatively common. Taxes and subsidies typically affect all consumers. The intervention assessed in the analysis involves fiscal measures that will both increase the price of foods with a high fat content (e.g. many dairy products) by $10 \%$ and will decrease the price of fruit and vegetables in the same proportion. No assumptions are made as to what specific measures should be taken to achieve those price changes. We modelled the effects fiscal interventions only through changes in consumption of fat and fruit and vegetables, based on some of the most conservative estimates of the price elasticity of demand for foods high in fat and for fruit and vegetables, among the nine studies reviewed in a recent French Government report (14). A $10 \%$ change in price will produce, on average, a $2 \%$ 
change in consumption in the opposite direction. Depending on the baseline levels of consumption in the countries concerned, the above price change will generate increases of between 4 and 7 grams of fruit and vegetable consumption per day and reductions in the proportion of total energy intake from fats of about $0.74 \%$. The estimated cost of per capita of fiscal measures in Europe is about 0.28 US\$ PPP.

\section{Protecting children from food advertising}

Heavy marketing of fast food and energy-dense food is regarded as a potential causal factor in weight gain and obesity, particularly because of its impact on dietary habits in children and teenagers. The intervention is targeted to children between the ages of 2 and 18. The intervention is intended to limit children's exposure to food advertising on television, particularly in programmes primarily aimed at children and during times of the day when a large proportion of the audience is made up by children in the above age group. Two versions of the intervention were assessed in the analysis: the first involving formal government regulation introduced by law and enforced by communication authorities; the second involving self-regulation by the food industry and broadcasters, with the government acting only in a monitoring and supervisory role. The effects of children's exposure to (fast) food advertising on BMI was estimated on the basis of the findings reported by Chou et al. (15). The impact of government regulation on children's exposure to food advertising was based on an evaluation of the impact of OFCOM's regulatory measures in the United Kingdom (16). As a result of restrictions in advertising, children aged $4-9$ will see $39 \%$ less advertising of foods high in fat, salt, or sugar, while children aged $10-15$ will see $28 \%$ less. Depending on the overall amount of television viewing by children in different countries, and on the amount of food advertising broadcast, children's BMI in the above age groups will be reduced by 0.16 to 0.34 points. The estimated cost of per capita of government regulation of food advertising to children in Europe is about 1.4 US\$ PPP, while the industry self-regulation option would cost about 0.10 US\$ PPP per capita.

\section{Informing consumers on food nutritional contents}

Disclosure of the nutritional characteristics of food sold in stores through labels reporting easy-to-read "nutrition facts" helps consumers choose healthier diets and may provide strong incentives for food manufacturers to decrease serving size and reformulate packaged food with healthier nutrients.

The intervention entails the adoption of a mandatory food labelling scheme for food sold in stores. Intervention characteristics and effectiveness are based on evidence provided in (17-18). Evidence suggests that this will increase the consumption of fruit and vegetables by an average of 10 grams per day, and reduce the proportion of total energy intake from fats by $0.42 \%$. The average $\mathrm{BMI}$ 
reduction that will be achieved in the population exposed to the intervention is 0.02 points. The estimated cost of per capita of introducing compulsory food labeling regulation in Europe is about 2.16 US\$ PPP.

\subsection{Counselling individuals at-risk in primary care}

In many OECD countries most citizens have a primary care physician who acts as their first point of contact with the health service and as a usual source of primary health care. Primary care physicians are also an important source of information and advice on lifestyles and the prevention of chronic diseases. However, such advice is not offered systematically, and is generally provided in response to specific individual demands.

The intervention targets individuals between the ages of 25 and 65 who present at least one of the following risk factors: a BMI of $25 \mathrm{~kg} / \mathrm{m} 2$ or above, high cholesterol $\left(75^{\text {th }}\right.$ percentile or above), high systolic blood pressure $(>140 \mathrm{mmHg})$, and type II diabetes. A more intensive version of the intervention involves additional counselling provided by a dietician upon referral. Intervention characteristics and effectiveness are modelled on the basis of a selection of studies which provide accounts of controlled experiments of counselling interventions in primary case (19-21).

In its more intensive form (physician and dietician counseling), the intervention will decrease the proportion of total energy intake from fats by almost $10 \%$, on average $(1.6 \%$ in the less intensive version, in which counseling is only provided by physicians), it will reduce BMI by 2.32 points ( 0.83 in the less intensive version), it will reduce blood cholesterol by $0.55 \mathrm{mmol} / \mathrm{l}(0.12)$, and systolic blood pressure and by $12 \mathrm{mmHg}$ (2.30). The estimated cost of per capita of a counseling intervention run by physicians and dieticians in primary care in Europe is about 15.23 US\$ PPP, while the cost of the less intensive version of the programme is about 7.16 US\$PPP.

\section{The Chronic Disease Prevention model}

The OECD and the WHO jointly developed a micro-simulation model called Chronic Disease Prevention (CDP) which implements a "causal web" of lifestyle risk factors for selected chronic diseases (Figure 1). This model was initially used to estimate the impact of interventions (the same examined here) in the EUR-A WHO region (1). Risk factors range from more distant exposures ("distal risk factors"), which are several steps away from disease events in the chain of causation, to more proximate exposures ("proximal risk factors"), more immediately connected to disease events. The causal web concept involves mutual influences among risk factors, which therefore have both direct and indirect impacts on chronic diseases. The model explicitly accounts for three groups of chronic diseases: stroke, 
ischemic heart disease and cancer (including lung, colorectal and female breast cancer). Proximal risk factors, such as high blood pressure, high cholesterol and high blood glucose, have a direct influence on the probability of developing the above chronic diseases, based on established pathophysiological mechanisms. Conversely, distal risk factors such as low intake of fruit and vegetables, high fat intake and insufficient physical activity have an indirect influence on chronic diseases. The indirect effect is mediated in part by the body mass index (BMI), which acts on proximal risk factors as well as directly on disease events. The model accounts for mortality from all causes of death and assumes that mortality associated with diseases that are not explicitly modelled remains stable at the rates currently observed in the relevant populations. The model simulates the dynamics of a given country or regional population over a lifetime period (set at 100 years in order to capture the full effectiveness of all interventions, including those targeting young children), although impacts can be assessed at any point in time. Births, deaths and the incidence and prevalence of risk factors and chronic diseases are modelled accordingly, based on the best existing epidemiological evidence for the relevant countries from a range of sources, including WHO, FAO and IARC datasets, national health surveys and published studies. A diagrammatic representation of the model is shown in the figure below. Future costs, as well as future health effects, were discounted at a $3 \%$ rate. The model was programmed using a software called ModGen (www.statcan.gc.ca/spsd/Modgen.htm), which is a generic "Model Generator" language created by Statistics Canada for developing and working with micro-simulation models.

The CDP model requires a series of epidemiological input data by gender, class of age (0 to 100) and socio-economic status. A first group of parameters allows the software to model population changes over time. This includes global mortality, fertility and the demographic structure of the population. A second group of parameters relates to the three levels of risk factors (i.e. distal, intermediate and proximal). This group includes the following epidemiological parameters: prevalence, incidence of new cases, remission rates, and relative risks (RRs) for higher level risk factors. A third and last group of parameters is used to model diseases. This includes prevalence, incidence rates, remission rates, relative rates (RRas) of disease for different risk factors, and case-fatality hazards (risk of dying of a disease for individuals who have that chronic disease).

We used the best available sources of information on the epidemiology of risk factors and chronic diseases to populate the micro-simulation model. When it was not possible to find input parameters from existing sources, these were calculated based on other parameters using the WHO software DisMod II, or through the analysis of data from national health surveys. 


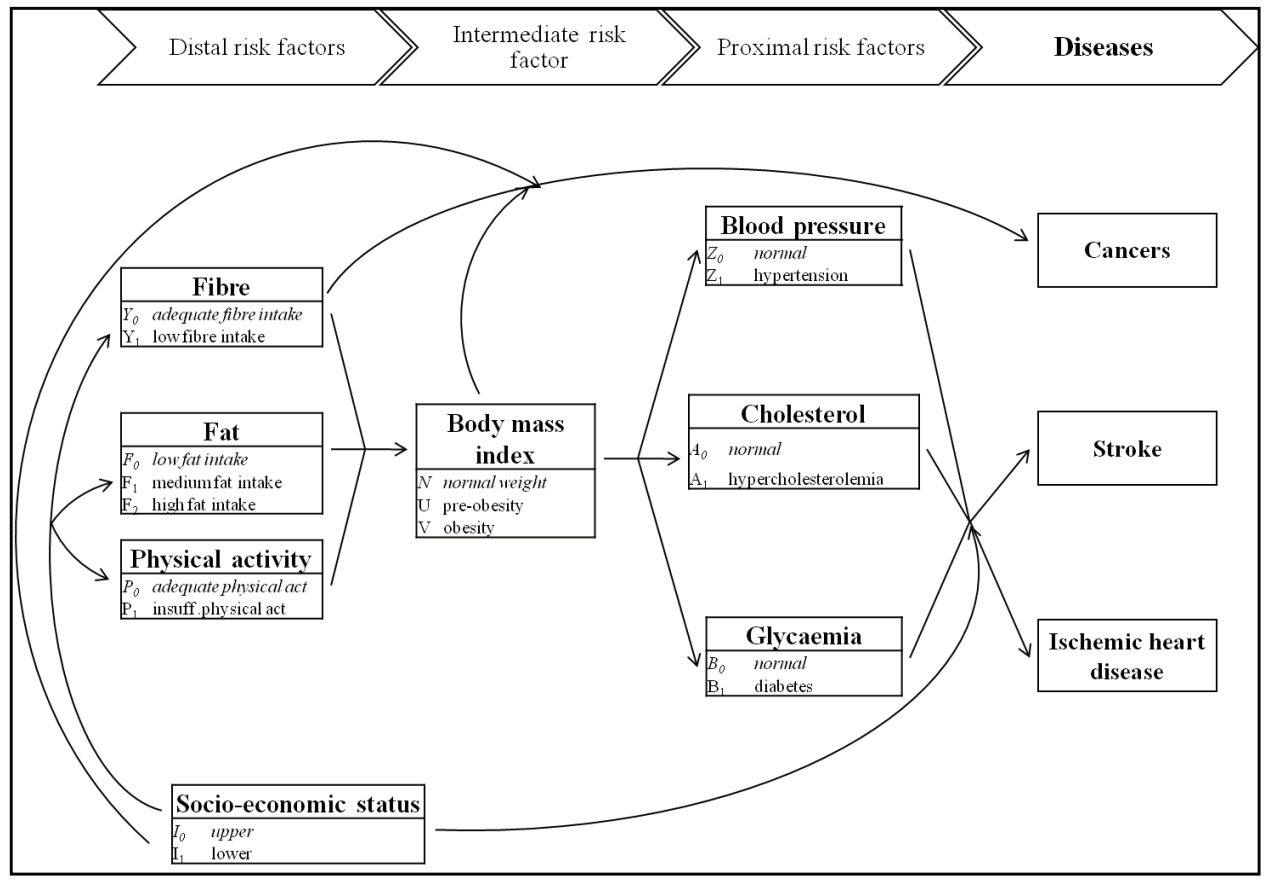

Figure 1. Causal web of risk factors and diseases implemented in the CDP model.

\section{Results}

\subsection{Effects of the interventions on obesity, health and life expectancy}

Interventions to improve diets and increase physical activity have the potential to reduce obesity rates, decrease the incidence of ischaemic heart disease, stroke and, to a lesser extent, the incidence of at least three forms of cancer. The impact of interventions on the morbidity associated with these chronic diseases is generally larger than their impact on mortality. Prevention in many cases delays the onset of chronic diseases, rather than preventing them altogether.

If they were to be implemented in isolation, interventions would generate a reduction in the number of people who are obese in the order of four to five percent, at best, although the majority of interventions would have substantially smaller impacts. This may seem a modest achievement, but in fact measuring changes in obesity rates is a rather inadequate way of assessing the value of such interventions. Many more people benefit from prevention than those who actually make it across the line that formally separates obesity from non-obesity thanks to those interventions. Improving one's own lifestyle and loosing weight will generate beneficial effects on health regardless of the BMI category in which someone is classified. 
The outcomes that matter the most when assessing the impacts of prevention are mortality and the occurrence of chronic diseases, or morbidity. Accordingly, health outcomes are measured in this analysis in terms of life years (LYs) gained through prevention (reflecting improvements in mortality) and disability-adjusted life years (DALYs) averted (reflecting the combined effect of prevention on mortality and morbidity). These outcomes capture comprehensively the ultimate impacts of prevention on health and longevity, although they fall short of reflecting some of the more subtle effects of improved lifestyles on quality of life, particularly in terms of psychological wellbeing and social functioning. Life years and DALYs are also widely used as outcome measures in economic evaluations of health interventions in areas other than prevention, which facilitates comparisons across a broad spectrum of options in setting priorities for health expenditures.

Figure 2 shows the average yearly increase in health outcomes (life years and disability-adjusted life years) for all interventions relative to the baseline scenario. Results are presented for the whole population. For all the interventions, the gain in disability-adjusted life years is higher than the gain in life years. In practical terms, this means that interventions are more effective in reducing morbidity (by delaying the onset of chronic diseases) than in reducing mortality.

Intensive primary care counselling is the intervention providing the highest gain both in terms of disability-adjusted life years and life years. Overall, by assuming a life expectancy of about 80 years, it generates a gain of 1 year of life every 12 individuals and 1 year of disability-adjusted life every 10 persons. On the other hand, mass media campaigns rank lowest, generating a gain of 1 life year/disabilityadjusted life year every 115/121 individuals. While all other programmes present a linear increase in their effectiveness on health outcome, physician/dietician counselling appears to be an outlier and presents, by far, the largest improvements. However, it should be remembered, that this is a particular intensive intervention targeting a specific group and providing tailored programmes. This is reflected also in the costs of implementing such programme.

The next set of figures (Figure 3 ) reports the gain in life years and disease adjusted life years by class of age. As expected, interventions show to have almost no effect on people less than 40 years old. Our model incorporates chronic diseases typically affecting middle-age or elderly individuals, therefore even if some interventions do decrease the prevalence of intermediate (i.e. BMI) and proximal (e.g. high blood pressure) risk factors in young people, the effects on diseases are not immediately visible because the risk factors need time to cause the disease and, in any case, the incidence of the diseases is so low that the effect is not appreciable. 


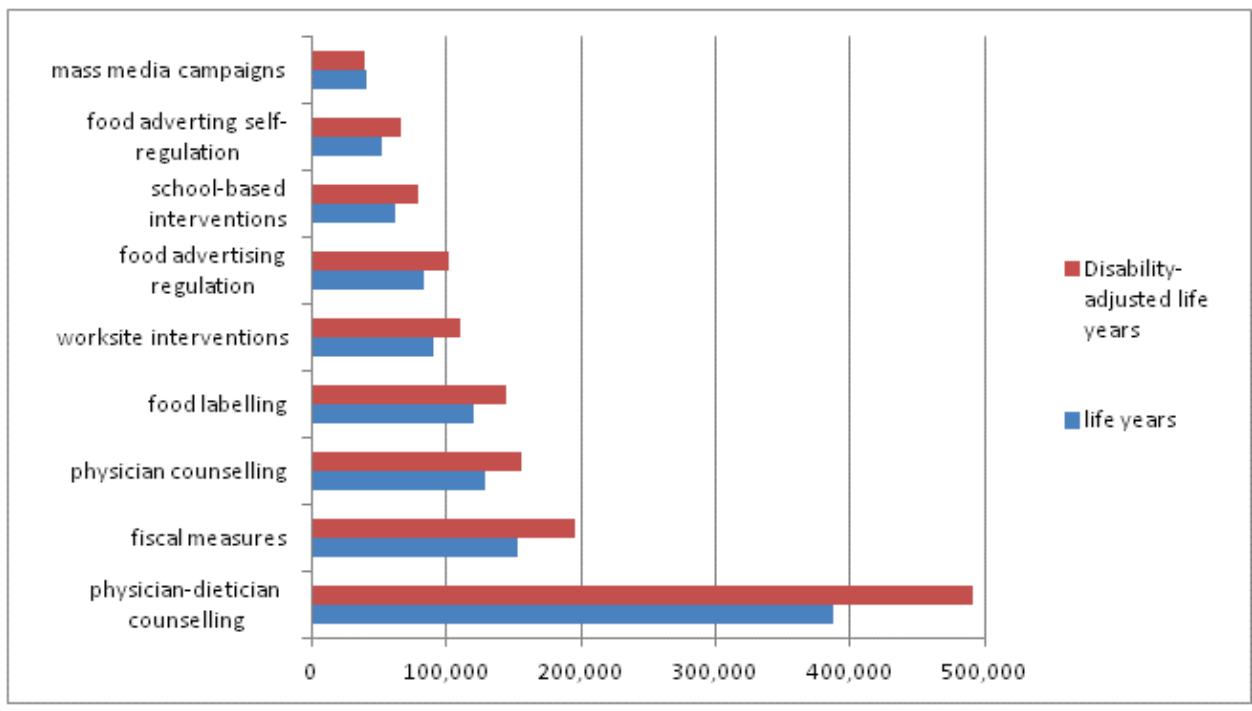

Figure 2. Health outcomes at the population level (average effects per year).

Additionally, it should be noted that gains in DALYs are higher in the age group 4180 while gains in life years are, for many interventions, higher in the age groups 81-100. This is due to the nature of chronic diseases, generally entailing a slow course of the disease before death, and to the effects of preventive interventions which delay the onset of diseases. As a consequence, in the age group 40 to 80 , the decrease of new cases produces an higher gain in disability-adjusted life years (i.e. with no chronic diseases). As the population gets older, the incidence of the diseases increases and consequently the impact on disability-adjusted life years weakens. At the same time, in the scenario without interventions people who are now 80 years old and who had developed diseases when they were younger start dying while under the intervention scenario they only start developing the disease. Consequently there is an increase in life years and a relative decrease in disability-adjusted life years.

\section{School-based interventions}

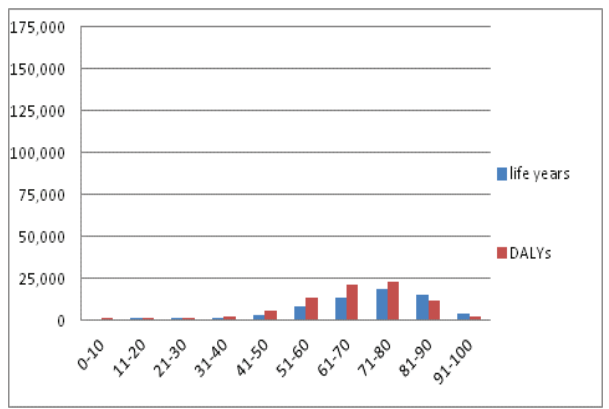

Worksite interventions

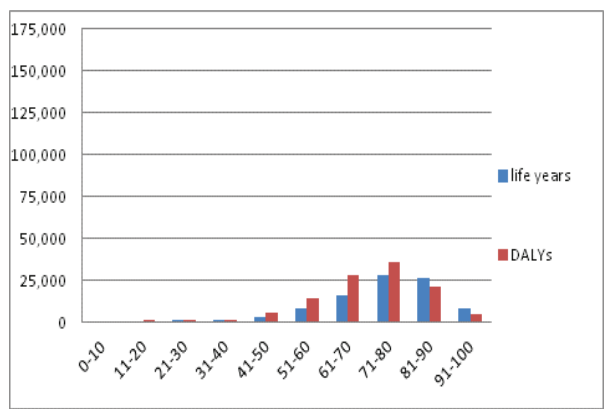


Mass media campaigns

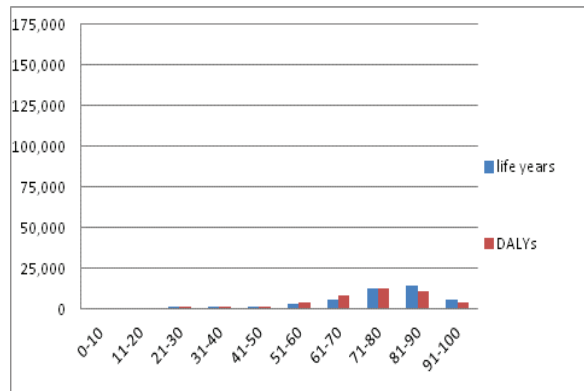

Physician counselling

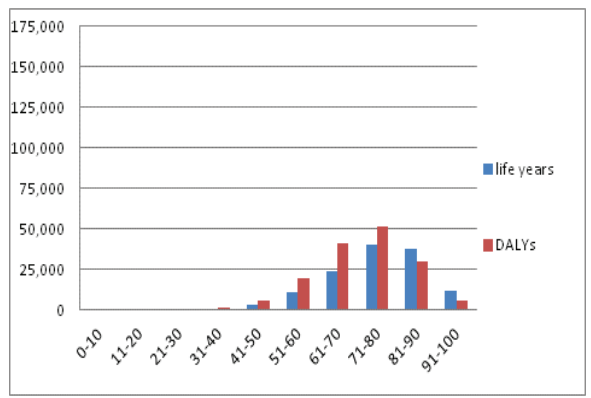

Food advertising regulation

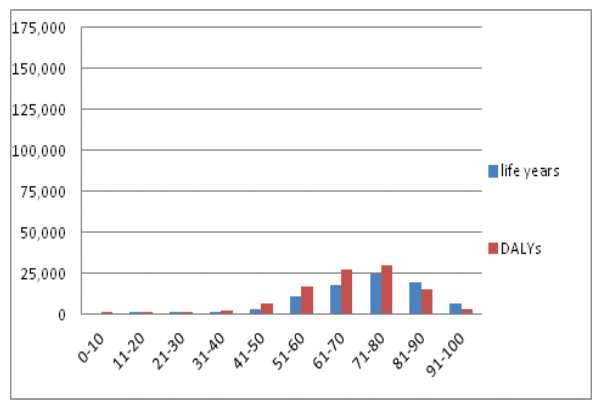

Food labelling

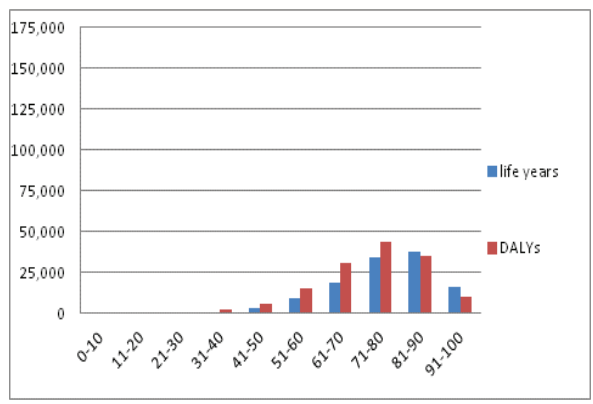

Fiscal Measures

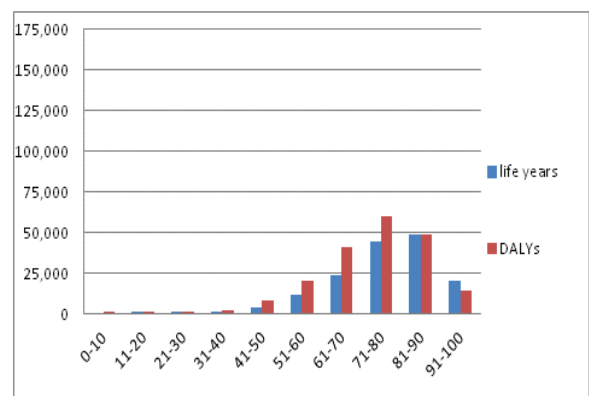

Physician-dietician counselling

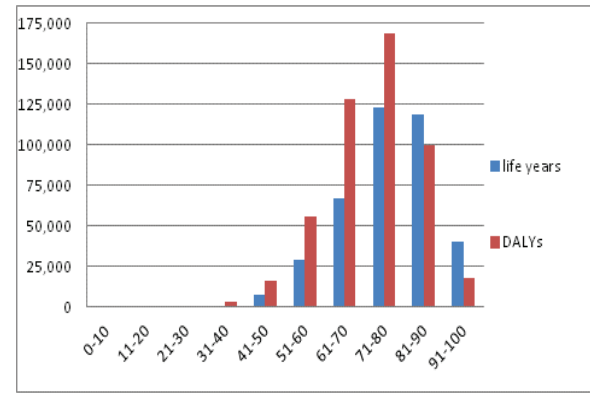

\section{Food advertising self-regulation}

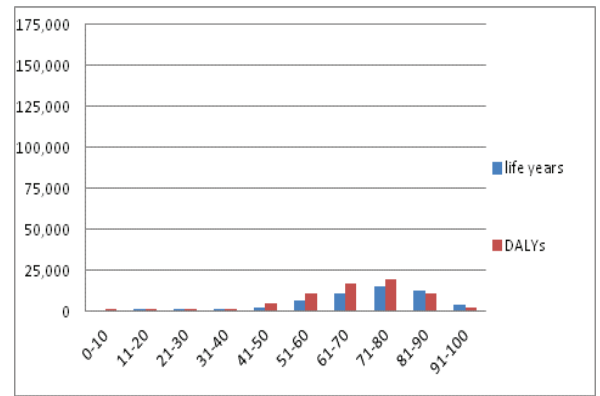

Figure 3. Health outcomes at the population level by age groups (average effects per year). 
Figure 4 shows the cumulative effectiveness of interventions over time. The vertical axis shows the number of disease adjusted life years while the horizontal axis shows the time frame of our analysis. Disability-adjusted life years are discounted at a $3 \%$ rate. Intensive primary care counselling is, by far, the most effective intervention. The second best performing intervention, primary care counselling, yields a total effect that is less than a third of physician-dietician counselling. Fiscal measures and food labelling schemes and worksite interventions show similar effectiveness in the early years, but, in the long run, fiscal measures have a larger impact. As noted in relation to previous figures, interventions targeting children yield significant results only after about $50-60$ years.

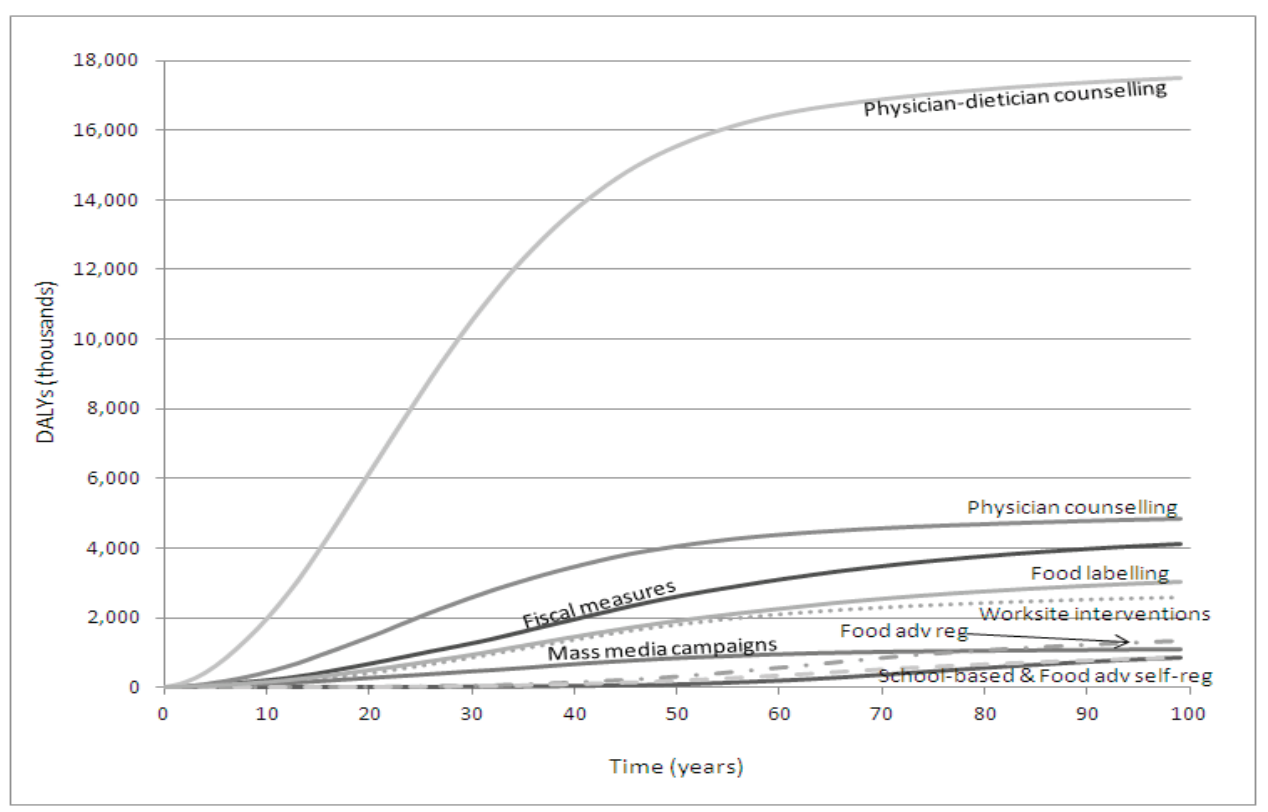

Figure 4. Cumulative disability-adjusted Ife years saved over time.

\subsection{Intervention costs and impact on health expenditure}

Prevention produces multiple and sometimes interacting effects, which are difficult to predict. For instance, certain forms of prevention may substantially reduce future health care costs, but often this will not be the case. Prevention may reduce fatality rates associated with certain chronic diseases and extend life with those diseases, which may increase overall health care costs in the long run. Individuals who live longer as a result of prevention will also develop diseases other than those targeted by prevention, which may require treatment and increase health expenditure.

The preventive interventions assessed in this analysis reflect a wide variety of approaches and are based in diverse settings. The costs associated with those 
interventions may arise in different jurisdictions. Some of the costs are typically paid through public expenditure (e.g. the costs associated with regulatory measures), others typically not (e.g. most of the costs associated with worksite interventions). Some of the costs arise within the health sector (e.g. health care costs), others arise within other sectors of government intervention (e.g. most of the costs associated with school-based interventions).

Figure 5 describes the average yearly economic impact of the interventions. The diagram reports both the costs of the interventions and their impacts on health expenditure. All interventions, with the exception of food advertising regulation, decrease health expenditures for the conditions explicitly included in the model (cancer, IHD, stroke, diabetes, high cholesterol, high systolic blood pressure), therefore effects on health expenditure are reported with a negative sign. Costs reported in Figures 4 are expressed in millions of dollars.

Physician/dietician counselling is the most expensive intervention with expected costs of about US\$ PPP 5.4 billion (before discounting) per year, while self-regulated advertising restrictions is the least expensive intervention, costing about US\$PPP 37 million every year. Fiscal measures generate reductions in health expenditure which more than offset intervention costs, thus leading to savings of about US\$ PPP 326 million.

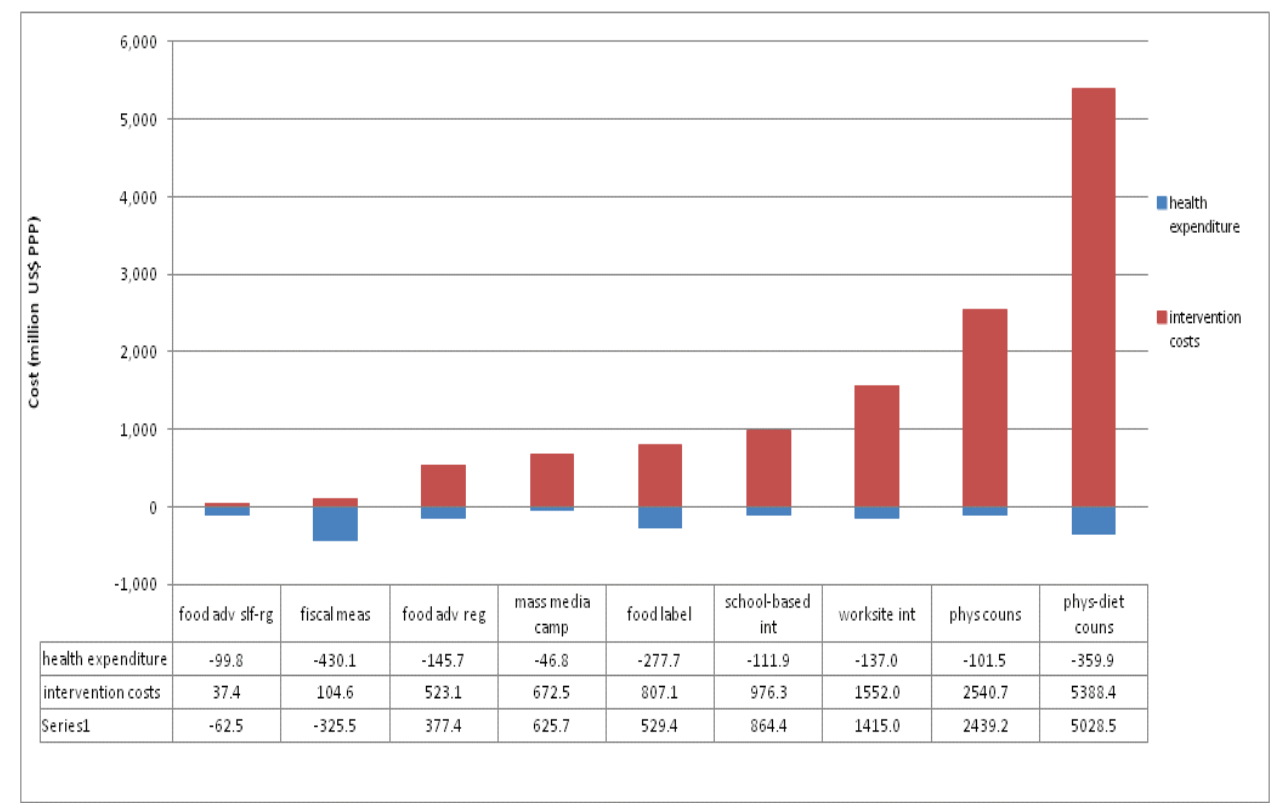

Figure 5. Economic impact at the population level (average effects per year).

In general, interventions generate savings in most age groups but become consistently more expensive than the baseline in the oldest age group. The main cause of this is the increased life expectancy of the population: the number of 
individuals and, accordingly, the number of individuals with a disease is higher in the intervention scenario and, consequently, the costs for treating those with diseases increase as well. It is important to emphasise that the costs illustrated in Figure 4 reflect health care resources devoted to the treatment of the diseases and risk factors explicitly included in the model. If a broader definition of health care costs had been assumed, encompassing the treatment of all diseases, it is plausible that overall savings would have been smaller.

\subsection{Assessment of the cost-effectiveness of interventions}

In the first 20-30 years of their implementation the cost-effectiveness ratios of some of the interventions examined are extremely high. In general, the scale of the impact of individual interventions is limited by the difficulties involved in reaching a large proportion of the national population, either because only certain age groups are targeted by the intervention, in which case it may take many years before a large share of the population receives some exposure to the intervention, or because compliance rates are low, as is typically the case for several of the interventions examined, based on existing evidence.

Figure 6 shows the cost-effectiveness ratios for each of the preventive interventions at different points in time over the 100 years of the simulation. Both costs and effectiveness are discounted at a $3 \%$ rate. Food labelling, mass media campaigns and physician-dietician counselling appear to have favourable cost-effectiveness ratios from the early years after their implementation. These three interventions are characterized either by a relatively small cost of implementation, less than US\$ PPP 2.2 per capita, combined with effects influencing a large share of the population or, as in the case of physician-dietician counselling, very large effectiveness. A second group of interventions, including physician counselling, worksite intervention, selfregulation of food advertising, reaches a cost-effectiveness of $\$ 50,000$ after about 30 years from the initial implementation. School-based interventions and food advertising regulation need respectively 90 and 55 years to reach similar values. Fiscal measures generate net savings shortly after their implementation. 


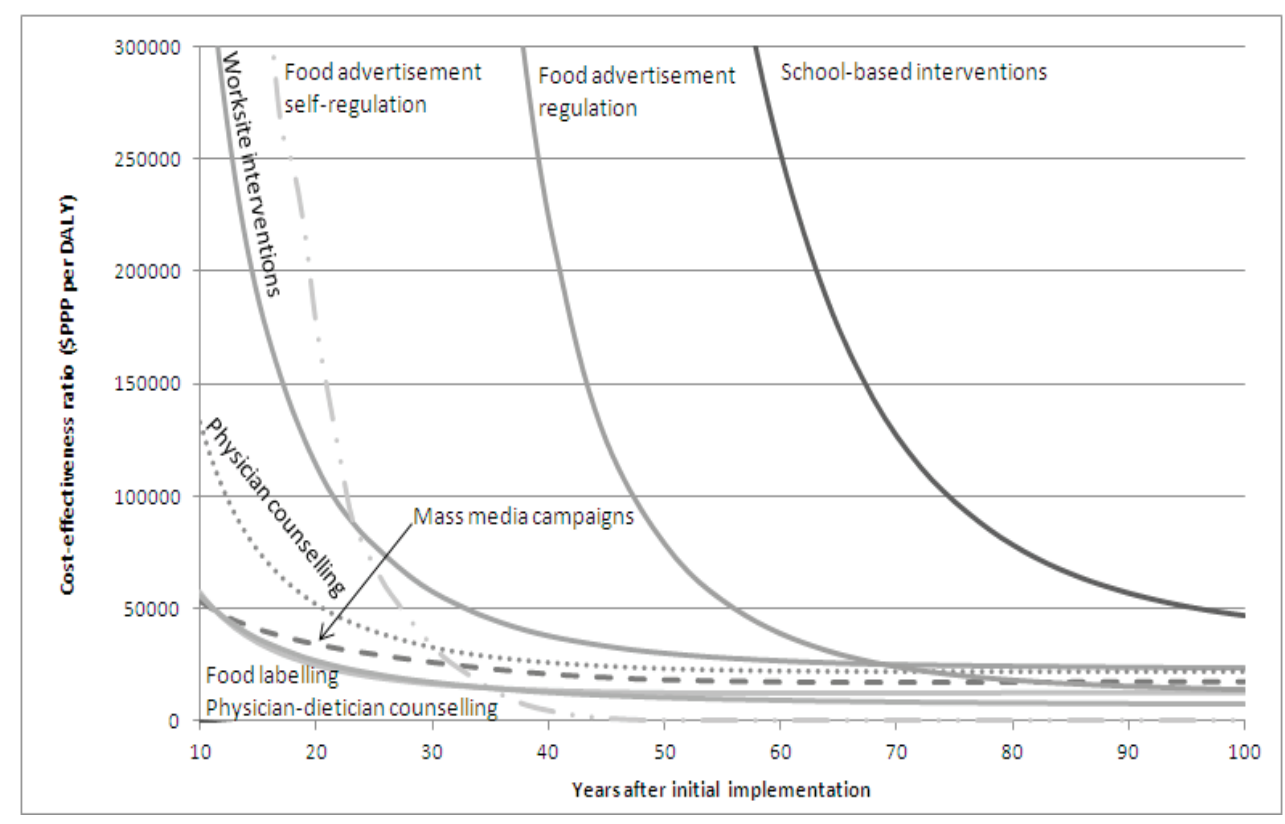

Figure 6. Cost-effectiveness of interventions over time.

\section{Strategies involving multiple interventions}

The potential impact of a combination of 5 interventions was explored, including regulatory interventions such as compulsory food labelling and industry selfregulation of food advertising to children, worksite and school-based health promotion programmes, and intensive counselling of individuals at risk in primary care. This combination of interventions provides a balanced coverage of different age groups (children and adults) using both regulation and health promotion approaches. In addition, it targets high-risk individuals with a more focused intervention which has been shown to be particularly effective in previous analyses. Our findings suggest that, even employing conservative assumptions about how interventions interact each others, a comprehensive prevention strategy that includes population interventions (e.g. food labelling and mass media campaigns) with interventions on high-risk individuals (e.g. counselling in primary care) consistently provides higher health benefits and a better impact on the health expenditure with a cost-effectivness ratio that goes below a threshold of 50,000 US\$ PPP after about 30 years since the implementation of such strategy. 


\section{Conclusions}

Most of the preventive interventions evaluated as part of the project appear to have favourable cost-effectiveness ratios. Therefore, those interventions may be regarded as efficient uses of resources when their benefits are measured in terms of life years, or disability-adjusted life years, gained relative to a scenario in which no systematic prevention is undertaken and chronic diseases are treated once they emerge. However, cost-effectiveness ratios do not provide information on the scale of the overall effects and costs associated with preventive interventions. Since the determinants of obesity are multi-factorial and affect all age groups and social strata, interventions tackling individual determinants or narrowly targeted to one groups of individuals will have a limited impact at the population level, and will not reduce significantly the scale of the obesity problem.

Among the most important reasons for the limited overall impact of some interventions, when considered in isolation, are the difficulties involved in reaching large sectors of national populations and in securing active participation in such programmes. In fact, the interventions that are capable of reaching the largest numbers of individuals (e.g. mass media campaigns, or fiscal measures), are among those that appear to have the largest impacts, even if their effects are smaller at the individual level. Interventions that target younger age groups are unlikely to have any significant health effects at the population level for many years. The cost-effectiveness profiles of such interventions may be favourable in the long-term, but may remain unfavourable for several decades at the start of the interventions.

Although the most efficient interventions appear to be outside the health sector, health care systems can make the largest impact on obesity and related chronic conditions by selecting individuals at high risk and by using existing facilities, particularly in primary care, to deliver effective counselling. However, it is also possible that the outcomes of primary-care-based interventions appear superior to those of other interventions because a more detailed assessment of their impact on risk factors could be made in a clinical setting.

Preventive interventions do not always generate reductions in health expenditure, even when the analysis is limited to a set of diseases that are more directly affected by diet, physical activity and obesity. Individuals may live longer with chronic diseases, as a result of prevention, and may survive long enough to experience unrelated diseases which they would not have experienced otherwise. Most of the interventions assessed in the economic analysis generate a requirement for additional resources to be made available within the health sector, in other areas of government intervention, or within the private sector. Interventions appear to be efficient uses of such resources, however, a large part of those resources would need to be made available upfront, while health returns are often delayed. Governments should determine what level of resources (budgets) they are willing 
and able to assign to prevention, and they may use the findings of this economic analysis to assess what portfolio of interventions would make the best use of such budgets.

\section{Acknowledgements}

Responsibility for the final report rests with the authors. The views expressed are those of the authors and not necessarily those of the OECD, the World Health Organization, or their member countries.

\section{References}

1. Sassi F, Cecchini M, Lauer J, Chisholm D. Improving lifestyles, tackling obesity: the health and economic impact of prevention strategies. OECD Health Working Paper No. 48. Paris: OECD Publishing, 2009.

2. Dixon H, Borland R, Segan C, Stafford H, Sindall C. Public reaction to Victoria's '2 Fruit and 5 Veg Every Day' campaign and reported consumption of fruit and vegetables. Prev Med 1998; 27(4): 572-82.

3. Foerster SB, Kizer KW, Disogra LK, Bal DG, Krieg BF, Bunch KL. California's '5-a-day-for better health' campaign: an innovative population-based effort to effect large scale dietary change. Am J Prev Med 1995; 11(2): 124-31.

4. Craig CL, Tudor-Locke C, Bauman A. Twelve-month effects of canada on the move: a population-wide campaign to promote pedometer use and walking. Health Educ Res 2007; 22(3): 406-13.

5. Gortmaker SL, Cheung LW, Peterson KE, Chomitz G, Cradle JH, Dart H, et al. Impact of a school-based interdisciplinary intervention on diet and physical activity among urban primary school children: eat well and keep moving. Arch Pediatr Adolesc Med 1999; 153(9): 975-83.

6. Luepker RV, Perry CL, Osganian V, Nader PR, Parcel GS, Stoen EJ, et al. The child and adolescent trial for cardiovascular health (CATCH). J Nutr Biochem 1998; 9(9): 525-34.

7. Perry CL, Bishop DB, Taylor G, Murray DM, Mays RW, Dudovitz BS, et al. Changing fruit and vegetable consumption among children: the 5-a-Day Power Plus program in St. Paul, Minnesota. Am J Public Health 1998; 88(4): 603-9.

8. Reynolds KD, Franklin FA, Binkley D, Raczynski JM, Harrington KF, Kirk KA, et al. Increasing the fruit and vegetable consumption of fourth-graders: results from the high 5 project. Prev Med 2000; 30(4): 309-19.

9. Sorensen G, Thompson B, Glanz K, Feng Z, Kinne S, DiClemente C, et al. Worksitebased cancer prevention: primary results from working well trial. Am J Public Health 1996; 86(7): 939-47.

10. Sorensen G, Stoddard A, Hunt MK, Hebert JR, Ockene JK, Avrunin JS, et al. The effects of a health promotion-health protection intervention on behavior change: the WellWorks Study. Am J Public Health 1998; 88(11): 1685-90. 
11. Sorensen G, Stoddard A, Peterson K, Cohen N, Hunt MK, Stein E, et al. Increasing fruit and vegetable consumption through worksites and families in the treatwell 5-a-day study. Am J Public Health 1999; 89(1); 54-60.

12. Emmons KM, Linnan LA, Shadel WG, Marcus B, Abrams DB. The Working Healthy Project: a worksite health promotion trial targeting physical activity, diet and smoking. J Occup Environ Med 1999; 41(7): 545-55.

13. Buller DB, Morrill C, Taren D, Aickin M, Sennott-Miller L, Buller MK, et al. Randomized trial testing the effect of peer education at increasing fruit and vegetable intake. J Natl Cancer Inst 1999; 91(17): 1491-500.

14. Hespel V, Berthod-Wurmser M. La pertinence et la faisabilité d'une taxation nutritionnelle. Paris: Inspection Générale de Finances et Inspection Générale des Affaires Sociales, 2008.

15. Chou S, Rashad I, Grossman M. Fast-food restaurant advertising on television and its influence on childhood obesity. J Law Econ 2008; 51(4): 599-618.

16. OFCOM. Changes in the Nature and Balance of Television Food Advertising to Children: a review of HFSS advertising restrictions. Available 10. 6. 2011 on: www.ofcom.org.uk/research/tv/reports/hfssdec08.

17. Variyam JN. Do nutrition labels improve dietary outcomes?. Health Econ 2008; 17(6): 695-708.

18. Variyam JN, Cawley J. Nutrition Labels and Obesity. NBER Working Paper No. 11956. Cambridge, MA: National Bureau of Economic Research, 2006.

19. Ockene IS, Hebert JR, Ockene JK, Merriam PA, Hurley TG, Saperia GM. Effect of training and a structured office practice on physician-delivered nutrition counseling: the Worcester-Area Trial for Counseling in Hyperlipidemia (WATCH) Am J Prev Med 1996; 12(4): 252-8.

20. Hebert JR, Ebbeling CB, Ockene IS, Ma Y, Rider L, Merriam PA, et al. A dieticiandelivered group nutrition program leads to reductions in dietary fat, serum cholesterol and body weight: the Worcester-Area Trial for Counselling in Hyperlipidaemia (WATCH). J Am Diet Assoc 1999; 99(5): 544-52.

21. Pritchard DA, Hyndman J, Taba F. Nutritional counselling in general practice: a cost-effective analysis. J Epidemiol Community Health 1999; 53(5): 311-6. 